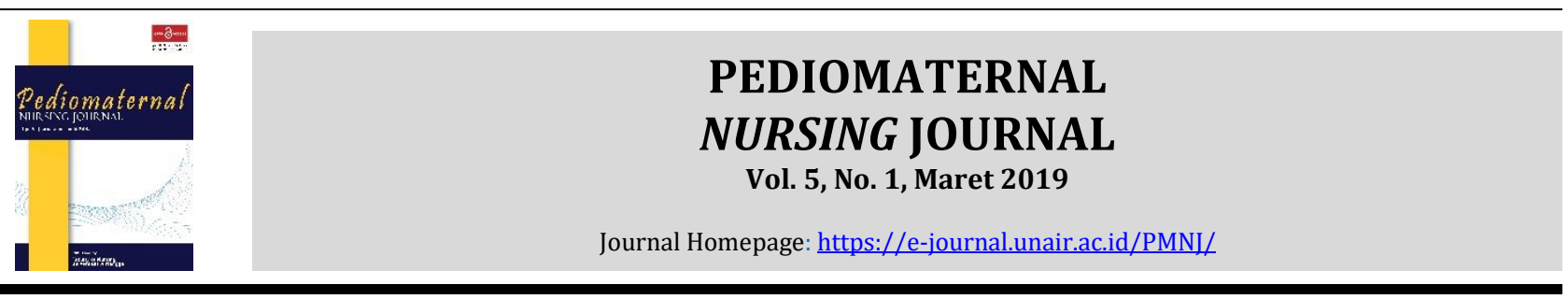

Original Research

\title{
Faktor Strategi Koping pada Pasien Kanker yang Menjalani Kemoterapi
}

\author{
(Coping Strategy Factors in Cancer Patients Undergoing Chemotherapy)
}

\author{
Maria Evarista Sugo, Tiyas Kusumaningrum, dan Rista Fauziningtyas
}

Fakultas Keperawatan, Universitas Airlangga, Surabaya, Jawa Timur, Indonesia

ARTICLE HISTORY
Received: March 21, 2019
Accepted: May 11, 2019
KEYWORDS
cancer; coping strategies;
chemotherapy; emotional; self-
concept
CORRESPONDING AUTHOR
Maria Evarista Sugo
maria.evarista.sugo-
2017@fkp.unair.ac.id
Fakultas Keperawatan,
Universitas Airlangga, Surabaya,
Jawa Timur, Indonesia

Cite this as:

\begin{abstract}
Introduction: Chemotherapy is one of the treatments for cancer that is effective and requires a considerable amount of time so that an adaptive coping strategy is needed from the patient. Patient coping strategies can be influenced by physical, psychological, and social factors. The purpose of this study was to analyze the factors associated with coping strategies for cancer patients undergoing chemotherapy at Prof. W Z Johannes Kupang Hospital.

Methods: The design in this study was cross-sectional. The total population were 163 and obtained 100 respondents by consequtive sampling. Independent variables were physical condition, emotional atmosphere, self-concept, and family support. The dependent variable was the coping strategy of cancer patients who undergo chemotherapy. The instrument used The Chemotheraphy Symptom Assessment Scale (C-SAS), Emotional Regulation Questionnaire (ERQ), self-concept, family support and The Cancer Coping Questionnaire. Data were analyzed with Spearman's Rho, and Pearson.

Results: There is a relationship between physical condition $(p=0.030)$, emotional condition $(p=0.001)$, self-concept $(p=0,000)$, family support $(p=0,000)$ with coping strategies for cancer patients who undergo chemotherapy.

Conclusion: Coping strategies in patients undergoing cancer can be affected by physical conditions while undergoing chemotherapy, psychological experienced by patients, and social support that can come from family and close relatives. Nurses who were close to patients during the chemotherapy process can also be a support system so that patients' coping strategies can be adaptive during chemotherapy.
\end{abstract}

Sugo, M. E., Kusumaningrum, T., \& Fauziningtyas, R. (2019). Faktor Strategi Koping pada Pasien Kanker yang Menjalani Kemoterapi. Pediomaternal Nurs. J., 5(1), 99-108.

\section{PENDAHULUAN}

Penyakit kanker masih menjadi masalah kesehatan utama di dunia dan menjadi penyebab kematian nomor dua setelah penyakit jantung dan pembuluh darah (1). Pasien kanker sering mengalami gangguan fisik, psikologis(suasana emosional,konsep diri)dan sosial(dukungan keluarga) (2). Salah satu penatalaksanaan penyakit kanker adalah dengan kemoterapi (3); (4). Obat yangdigunakan dalam kemoterapi bersifat karsinogenik, memerlukan penanganan khusus serta dapat menimbulkan efek samping yang dapat menyebabkan pasien tidak bersedia untuk melanjutkan terapi tersebut (5). Pasien kanker dengan kemoterapi banyak menunjukkan gejala stress fisik dan emosional seperti ansietas, depresi sebagai akibat yang buruk dari efek samping kemoterapi, ketidakpastian hasil dari pengobatan dan masalah psikologis lainnya (6). Dampak jangka panjang yang ditimbulkan dapat mengganggu proses perkembangan, gangguan mental, gangguan kualitas hidup dan isolasi sosial (7).

Sebanyak 8,2 juta orang meninggal dunia akibat kanker setiap tahunnya (8). Laporan Riset Kesehatan Dasar (9) diketahui prevalensi kanker adalah sebesar 1,4 per 1.000 penduduk atau sekitar (347.000) orang serta merupakan penyebab kematian nomor 7 (5,7\%) dari seluruh penyebab kematian (10). Pada tahun 2017 ini diprediksikan hampir 9 juta orang meninggal di seluruh dunia akibat kanker dan akan 
terus meningkat hingga 13 juta orang per tahun di 2030. Data BPJS Kesehatan menunjukkan peningkatan jumlah kasus kanker yang ditangani dan pembiayaannya pada periode 2014-2015 (11).

Studi pendahuluan yang dilakukan diketahui dari 93 pasien kanker yang menjalani kemoterapi di RSUD Prof. Dr. W.Z. Johanes Kupang pada bulan November 2017 jenis kanker yang terbanyak adalah kanker payudara sebanyak 52 orang, kemudian menyusul kanker ovarium sebanyak 8 orang, kanker serviks 7 orang, SCC gingival 6 orang dan sisanya adalah jenis kanker yang lain. Wawancara yang dilakukan dengan kepala ruangan kemoterapi diketahui setiap bulannya terdapat 3 sampai dengan 4 orang yang tidak tuntas menjalani kemoterapi (drop out) yang disebabkan tidak mampu menahan kerasnya efek samping kemoterapi, putus asa, takut akan kematian dan depresi. Wawancara dengan 3 orang pasien kanker yang sudah mengikuti sesi 3 kemoterapi diketahui bahwa semua penderita kanker memiliki mekanisme koping tidak efektif yang ditandai dengan mengeluh cemas, stres, dan takut kematian yang dapat terjadi kapan saja.

Faktor - faktor yang mempengaruhi strategi koping yang menurut (12) adalah materi, fisik, psikologis, sosial, dan spiritual. Strategi mekanisme koping adaptif menurut (13)yaitu emotional focused coping dan problem focused coping. Emotional focused coping merupakan strategi koping yang digunakan untuk mengatasi emosi negatif yang menyertainya, sedangkan problem focused coping merupakan strategi yang digunakan untuk mengatasi situasi yang menimbulkan stress pada pasien kanker, misalnya stres akibat efek samping obat. Strategi tersebut kemudian dikembangkan oleh (14) yaitu emotional focused coping yang terdiri dari konfrontasi (confrontative coping), mencari dukungan sosial (seeing social support), dan merencanakan pemecahan masalah (planful problem solving). Kemudian problem focused coping yang terdiri dari kontrol diri (self-control), membuat jarak (disturbancing), penilaian kembali secara positif (positive reappraice), menerima tanggung jawab (accepting responsibility), dan lari atau penghindaran (escape/avoidance).

Tindakan mengontrol tekanan emosional dengan strategi koping yang baik dapat dilakukan oleh penderita kanker yang baru terdiagnosis untuk menghindari cemas dan depresi (15). Penelitian yang dilakukan oleh (16) tentang koping pada pasien kanker diketahui dari 80 responden menunjukan rata-rata nilai koping yang masih rendah dan menurut (17) dengan mengontrol stressos saat menjalani kemoterapi dapat meningkatkan mekanisme koping yang adaptif.Strategi koping merupakan mekanisme adaptasi individu yang dilakukan secara sadar dan terarah dalam mengatasi rasa sakit atau menghadapi stressor yang ditimbulkan saat menjalani kemoterapi (18). Tujuan dari penelitian ini adalah untuk mengetahui tentang faktor - faktor yang mempengaruhi strategi koping pada pasien kanker yang menjalani kemoterapi.

\section{METODE}

\subsection{Desain}

Penelitian yang dilakukan merupakan jenis penelitian descriptive analitic dengan pendekatan cross sectional.

\subsection{Populasi, sampel, dan sampling}

Populasi pada penelitian ini adalah pasien kanker yang menjalani kemoterapi di RSUD Prof. W Z Johannes Kupang sebanyak 163 pasien dan didapatkan 100 sampel dengan consequtive sampling. Kriteria inklusi meliputi responden dengan usia $>18$ tahun, semua jenis kanker, dan responden dapat menulis dan berbahasa Indonesia. Kriteria eksklusi yaitu pasien dengan gangguan jiwa dan tidak kooperatif selama mengikuti penelitian.

\subsection{Variabel}

Variabel independen dalam penelitian ini adalah faktor fisik (kondisi fisik), faktor psikologis yang meliputi suasana emosional dan konsep diri, serta faktor sosial (dukungan keluarga). Variabel dependen dalam penelitian ini adalah strategi koping pasien kanker yang menjalani kemoterapi.

\subsection{Instrumen}

Kuesioner fisik menggunakan ChemotheraphySymptom Assesment Scale (C-SAS). C-SAS merupakan skala yang digunakan untuk menilai kondisi klinis pasien yang mendapatkan kemoterapi, dilihat dari tanda dan gejala yang dirasakan pasien akibat efek samping kemoterapi. C-SAS terdiri atas 24 pertanyaan (dimodifikasi jadi 23), dengan pilihan jawaban Iya dan Tidak. Jika pasien menjawab iya maka akan diberi skor 1 , namun jika menjawab tidak akan diberi skor 0. Hasil akhir dari pengisian kuesioner ini akan dikelompokkan menjadi 3 kategori, yaitu ringan (skor $\leq 7$ ), sedang (skor 7 -13), dan berat (skor $\geq 14$ ). Kuesioner Chemotheraphy Symptom Assesment Scale (C-SAS) dengan nilai Cronbach's Alpha 0,947 yang berarti sangat reliabel.

Kuesioner suasana emosional dukur dengan menggunakan kuesioner ERQ (Emotional Regulation Questionnaire). Kuesioner ini terdiri atas 10 item pernyataan dengan 6 item pernyataan mengukur cognitive reaprraisal dan 4 item mengukur expressive suppression. Kuesioner ini menggunakan skala $1-7$, namun peneliti hanya menggunakan rentang 1- 4 dengan 1 adalah pernyataan sangat tidak setuju dan 4 adalah pernyataan sangat setuju. Kuesioner ERQ (Emotional Regulation Questionnaire) dengan nilai Cronbach's Alpha 0,872 yang berarti sangat reliablel.

Konsep diri diukur dengan menggunakan kuesioner yang terdiri atas 20 pernyataan, yang dibagi kedalama 5 aspek, yaitu identitas diri (6 soal), gambaran diri (3) soal, ideal diri (3 soal), harga diri (4 soal), dan peran diri (4 soal). Pernyataan pada kuesioner terdiri atas 2 jenis yaitu pernyataan favorable dan unfavorable dengan rentang skor $1-4$ (sangat tidak setuju sampai dengan sangat setuju). 
Tabel 1. Distribusi Responden Menurut Karakteristik Demografi di RSUD Prof. W Z Johannes Kupang, Nusa Tenggara Timur pada 4-18 Desember 2018

\begin{tabular}{|c|c|c|c|}
\hline \multicolumn{2}{|r|}{ Karakteristik } & \multirow[t]{2}{*}{$\mathbf{f}$} & \multirow[t]{2}{*}{$\%$} \\
\hline Usia & & & \\
\hline 1. & Remaja Akhir (18-25) & 3 & 3 \\
\hline 2. & Dewasa Awal (26-35) & 20 & 20 \\
\hline 3. & Dewasa Akhir (36-45) & 29 & 29 \\
\hline 4. & Lansia Awal (46-55) & 24 & 24 \\
\hline 5. & Lansia Akhir (56-65) & 24 & 24 \\
\hline Total & & 100 & 100 \\
\hline \multicolumn{4}{|c|}{ Jenis Kelamin } \\
\hline 1. & Laki-laki & 32 & 32 \\
\hline 2. & Perempuan & 68 & 68 \\
\hline Total & & 100 & 100 \\
\hline \multicolumn{4}{|c|}{ Pendidikan Terakhir } \\
\hline 1. & SD & 22 & 22 \\
\hline 2. & SMP & 12 & 12 \\
\hline 3. & SMA & 33 & 33 \\
\hline 4. & Diploma & 12 & 12 \\
\hline 5. & Sarjana & 21 & 21 \\
\hline Tota & & 100 & 100 \\
\hline \multicolumn{4}{|c|}{ Pekerjaan } \\
\hline 1. & Tidak bekerja & 40 & 40 \\
\hline 2. & PNS & 27 & 27 \\
\hline 3. & Swasta & 16 & 16 \\
\hline 4. & Wiraswasta & 8 & 8 \\
\hline 5. & Lainnya(pensiun) & 9 & 9 \\
\hline Total & & 100 & 100 \\
\hline \multicolumn{4}{|c|}{ Jenis Kanker } \\
\hline 3. & Ca Cervix & 8 & 8 \\
\hline 4. & Ca Coli & 1 & 1 \\
\hline 5. & Ca Colon & 3 & 3 \\
\hline 6. & Ca Mamae & 35 & 35 \\
\hline 7. & Ca Ovarium & 22 & 22 \\
\hline 8. & Ca Parotis & 6 & 6 \\
\hline 9. & Ca Penis & 1 & 1 \\
\hline 10. & Ca Rectal & 1 & 1 \\
\hline 11. & Ca Recti & 4 & 4 \\
\hline 12. & Ca Rectum & 1 & 1 \\
\hline 13. & Ca Testis & 3 & 3 \\
\hline 14. & Ca Tyroid & 1 & 1 \\
\hline 15. & Gland Tumor & 1 & 1 \\
\hline 16. & KNF & 1 & 1 \\
\hline 17. & $\mathrm{LNH}$ & 5 & 5 \\
\hline 18. & Osteosarcoma & 1 & 1 \\
\hline 19. & Scc Ginggiva & 2 & 2 \\
\hline 20. & Scc Lidah & 1 & 1 \\
\hline 21. & SLE & 1 & 1 \\
\hline 22. & Tumor Paru & 2 & 2 \\
\hline Tota & & 100 & 100 \\
\hline \multicolumn{4}{|c|}{ Stadium } \\
\hline 1. & Stadium 1 & 7 & 7 \\
\hline 2. & Stadium 2 & 43 & 43 \\
\hline 3. & Stadium 3 & 38 & 38 \\
\hline 4. & Stadium 4 & 12 & 12 \\
\hline Tota & & 100 & 100 \\
\hline
\end{tabular}

Untuk penyataan favorable sangat tidak setuju diberi skor 1 , sangat setuju 4 , sedangkan untuk pernyataan unfavorable sangat tidak setuju diberi skor 4 dan sangat setuju diberi skor 1 . Kuesioner konsep diri dengan nilai Cronbach's Alpha 0,891 yang berarti sangat reliablel.

Kuesioner dukungan sosial menggunakan pertanyaan tipe multiple choice yaitu memilih jawaban dengan 4 kriteria yaitu mulai dari opsi selalu sampai dengan tidak pernah. Kuesioner dukungan keluarga ini memiliki 12 item pertanyaan yang mencakup 3 domain dukungan keluarga. Domain tersebut meliputi domain dukungan informasional, dukungan instrumental, serta dukungan emosional dan harga diri. Skoring dalam kuesioner ini menggunakan empat skala bernilai 0-3. Nilai 0 (tidak pernah), 1 (kadang-kadang), 2 (sering) dan 3 (selalu). 
Kuesioner respons sosial dengan nilai Cronbach's Alpha 0,883 yang berarti sangat reliabel.

Instrumen koping menggunakan the cancer coping questionnaire yang berisi 21 item pertanyaan, dengan kategori jawaban tidak pernah, kadang-kadang, sering dan sangat sering. Dari 21 pertanyaan, 14 pertanyaan wajib dijawab oleh semua responden, sedangkan 7 pertanyaan lainnya dijawab oleh
Peneliti sudah menjelaskan dan memberikan pengarahan kepada perawat terkait teknis penelitian.

\subsection{Analisis}

Penelitian ini dilakukan analisis dengan IBM SPSS Statistic 25 dengan uji Pearson Rho $\alpha \leq 0,05$ untuk data dengan distribusi normal dan Spearmen's Rho $\alpha$ $\leq 0,05$ untuk data dengan distribusi tidak normal.

Tabel 2. Distribusi Kategori Responden di RSUD Prof. W Z Johannes Kupang, Nusa Tenggara Timur pada 4-18 Desember 2018

\begin{tabular}{|c|c|c|c|}
\hline & Kategori & $\mathbf{f}$ & $\%$ \\
\hline \multicolumn{4}{|l|}{ Fisik } \\
\hline 1. Ringan & & 16 & 16 \\
\hline 2. Sedang & & 42 & 42 \\
\hline 3. Berat & & 42 & 42 \\
\hline Total & & 100 & 100 \\
\hline \multicolumn{4}{|l|}{ Suasana Emosi } \\
\hline 1. Baik & & 48 & 48 \\
\hline 2. Kurang & & 52 & 52 \\
\hline Total & & 100 & 100 \\
\hline \multicolumn{4}{|l|}{ Konsep Diri } \\
\hline 1. Positif & & 53 & 53 \\
\hline 2. Negatif & & 47 & 47 \\
\hline Total & & 100 & 100 \\
\hline \multicolumn{4}{|c|}{ Dukungan Keluarga } \\
\hline 1. Baik & & 63 & 63 \\
\hline 2. Kurang & & 37 & 37 \\
\hline Total & & 100 & 100 \\
\hline \multicolumn{4}{|l|}{ Strategi Koping } \\
\hline 1. Adaptif & & 82 & 82 \\
\hline 2. Maladaptif & & 18 & 18 \\
\hline Total & & 100 & 100 \\
\hline
\end{tabular}

responden yang memiliki pasangan (19). Hasil pengisian kuesioner dikategorikan menjadi 2 kelompok yaitu koping adaptif dengan rentang skor 20 - 40, dan koping maladaptif dengan rentang skor 41 - 80. The cancer coping questionnaire dengan nilai Cronbach's Alpha 0,914 yang berarti sangat reliablel.

\subsection{Prosedur}

Penelitian ini dilakukan di Ruang Kemoterapi RSUD Prof. W Z Johannes Kupang. Penelitian ini dilakukan pada 4 - 18 Desember 2018. Langkah yang pertama adalah menentukan responden yang sesuai dengan kriteria inklusi dan ekslusi yang telah ditetapkan oleh peneliti. Setelah responden ditentukan, selanjutnya peneliti memberikan penjelasan kepada responden terkait penelitian yang dilakukan meliputi jenis terapi yang akan diberikan, tujuan, dan manfaat dari penelitian. Jika responden setuju kemudian diberikan lembar informed concern sebagai tanda bersedianya responden untuk mengikuti kegiatan peneltian.

Setelah responden bersedia, selanjutnya peneliti membagikan kuesioner penelitian satu per satu kepada responden. Pada saat pengambilan data, peneliti mendampingi responden, sehingga kalau ada responden yang tidak mengerti terkait kuesioner penelitian, responden dapat langsung bertanya kepada peneliti. Peneliti melibatkan tim peneliti yang berasal dari rekan perawat sebanyak 2 orang untuk membantu dalam pengambilan data penelitian.

\subsection{Ethical Clearance}

Penelitian ini telah dinyatakan lolos kaji etik dan mendapatkan sertifikat Ethical Approval dengan No. 1193-KEPK yang dikeluarkan oleh Komite Etik Penelitian Kesehatan Fakultas Keperawatan Universitas Airlangga pada tanggal 3 Desember 2018.

\section{Hasil}

Karakteristik demografi responden sejumlah 100 orang di RSUD Prof. W Z Johannes Kupang, Nusa Tenggara Timur. Mayoritas usia responden dalam penelitian ini adalah dewasa akhir dengan rentang 36-45 tahun sebanyak 29 orang (29\%). Mayoritas responden adalah perempuan sebanyak 68 orang $(68 \%)$ dengan mayoritas pendidikan terakhir adalah SMA sebanyak 33 orang (33\%) diikuti pendidikan SD sebanyak 22 orang (22\%) dan sarjana sebanyak 21 orang (21\%). Mayoritas responden sudah tidak bekerja. Dalam penelitian ini, jenis kanker paling banyak adalah Ca Mamae dan Ca ovarium. Mayoritas responden sudah menderita kanker dengan stadium 2 [Tabel 1].

Distribusi kategori pada masing-masing variabel. Mayoritas responden dengan aktifitas fisik berat sebanyak 42 orang (42\%). Kemudian suasana emosi responden dalam kategori kurang sebanyak 52 orang (52\%) dan konsep diri yang positif sebanyak 53 orang (53\%). Mayoritas responden mendapat dukungan 
baik dari keluarga sebanyak 63 orang (63\%) serta memiliki strategi koping yang adaptif sebanyak 82 orang (82\%) [Tabel 2].

Mayoritas responden dengan aktivitas fisik yang sedang memiliki koping yang adaptif sebanyak 36 orang (36\%), sementara itu responden dengan aktifitas fisik yang berat miliki strategi koping yang adaptif sebanyak 32 orang (32\%). Sebagian besar responden yang miliki strategi koping yang konsep diri negative yang memiliki strategi koping yang adaptif sebanyak 36 orang (36\%). Hasil pearsonmenunjukkan terdapat hubungan yang sangat signifikan $(\mathrm{p}=0,000)$ antara konsep diri dengan strategi koping pada pasien yang menjalani kemoterapi dengan tingkat korelasi yang cukup kuat $(r=0,439)$ serta koefisien korelasi positif yang menunjukkan hubungan antara kedua variabel yang searah dengan nilai yang sama tinggi [Tabel 3].

Tabel 3. Hubungan Antara faktor Fisik, Suasana Emosi, Konsep Diri, dan Sosial dengan Strategi Koping Pasien kanker yang Menjalani Kemoterapi di RSUD Prof. W Z Johannes Kupang, Nusa Tenggara Timur pada 4-18 Desember 2018

\begin{tabular}{|c|c|c|c|c|c|c|c|c|}
\hline \multirow{3}{*}{ Variabel } & \multicolumn{4}{|c|}{ Strategi Koping } & \multirow{2}{*}{\multicolumn{2}{|c|}{$\Sigma$}} & \multirow{3}{*}{$\mathbf{p}$} & \multirow{3}{*}{$\mathbf{r}$} \\
\hline & \multicolumn{2}{|c|}{ Adaptif } & \multicolumn{2}{|c|}{ Maladaptif } & & & & \\
\hline & f & $\%$ & $\mathbf{f}$ & $\%$ & f & $\%$ & & \\
\hline \multicolumn{9}{|l|}{ Fisik } \\
\hline$\overline{\text { Ringan }}$ & 14 & 14 & 2 & 2 & 16 & 16 & \multirow{4}{*}{0,030} & \multirow{4}{*}{$-0,217$} \\
\hline Sedang & 36 & 36 & 6 & 6 & 42 & 42 & & \\
\hline Berat & 32 & 32 & 10 & 10 & 42 & 42 & & \\
\hline$\sum$ & 82 & 82 & 18 & 18 & 100 & 100 & & \\
\hline \multicolumn{9}{|c|}{ Suasana Emosi } \\
\hline Baik & 40 & 40 & 8 & 8 & 48 & 48 & \multirow[t]{3}{*}{0,001} & \multirow[t]{3}{*}{0,336} \\
\hline Kurang & 42 & 42 & 19 & 19 & 52 & 52 & & \\
\hline $\begin{array}{l}\sum_{\text {Konsep Di }} \\
\underline{\text { Sol }}\end{array}$ & 82 & 82 & 18 & 18 & 100 & 100 & & \\
\hline Baik & 46 & 46 & 7 & 7 & 53 & 53 & \multirow[t]{3}{*}{0,000} & \multirow[t]{3}{*}{0,439} \\
\hline Kurang & 36 & 36 & 11 & 11 & 47 & 47 & & \\
\hline $\begin{array}{l}\sum_{\text {Sosial }} \\
\end{array}$ & 82 & 82 & 18 & 18 & 100 & 100 & & \\
\hline$\overline{\text { Positif }}$ & 57 & 57 & 6 & 6 & 63 & 63 & \multirow[t]{3}{*}{0,000} & \multirow[t]{3}{*}{0,444} \\
\hline Negative & 25 & 25 & 12 & 12 & 37 & 37 & & \\
\hline$\sum$ & 82 & 82 & 18 & 18 & 100 & 100 & & \\
\hline
\end{tabular}

maladaptif juga memiliki aktivitas fisik yang berat sebanyak 10 orang (10\%). Hasil pearson menunjukkan terdapat hubungan yang cukup signifikan $(p=0,030)$ antara fisik dengan strategi koping pada pasien yang menjalani kemoterapi dengan tingkat korelasi sangat lemah $(r=-0,217)$ serta koefisien korelasi negatif yang menunjukkan hubungan antara kedua variabel yang berlawanan [Tabel 3].

Mayoritas responden dengan suasana emosi yang kurang memiliki koping yang adaptif sebanyak 42 orang (42\%), serta yang maladaptif sebanyak 19 orang (19\%). Sebagian besar responden yang miliki strategi koping yang maladaptif juga memiliki aktivitas fisik yang berat sebanyak 19 orang (19\%). Namun, responden dengan suasana emosi yang baik juga memiliki strategi koping yang adaptif sebanyak 40 orang (40\%). Hasil Spearman's Rho menunjukkan terdapat hubungan yang signifikan $(\mathrm{p}=0,001)$ antara suasana emosi dengan strategi koping pada pasien yang menjalani kemoterapi dengan tingkat korelasi yang cukup kuat $(r=0,366)$ serta koefisien korelasi positif yang menunjukkan hubungan antara kedua variabel yang searah dengan nilai yang sama tinggi,artinya semakin baik suasana emosi,maka strategi koping semakin baik [Tabel 3].

Mayoritas responden dengan konsep diri positif memiliki strategi koping yang adaptif sebanyak 46 orang (46\%) serta koping maladaptif sebanyak 7 orang $(7 \%)$. Namun, terdapat responden dengan
Mayoritas responden dengan dukungan keluarga yang positif memiliki strategi koping yang adaptif sebanyak 57 orang (57\%), namun juga terdapat yang memiliki strategi koping yang maladaptif sebanyak 6 orang (6\%). Sebagian besar responden yang memilikii strategi koping yang maladaptive juga memiliki dukungan keluarga yang negative sebanyak 12 orang (12\%). Hasil Spearman's Rho menunjukkan terdapat hubungan yang sangat signifikan $(\mathrm{p}=0,000)$ antara dukungan keluarga dengan strategi koping pada pasien yang menjalani kemoterapi dengan tingkat korelasi yang cukup kuat $(r=0,444)$ serta koefisien korelasi positif yang menunjukkan hubungan antara kedua variabel yang searah dengan nilai yang sama tinggi [Tabel 3].

\section{PEMBAHASAN}

\subsection{Faktor fisik}

Hasil analisis dengan uji statistik korelasi Spearman's $R ' h o$ adalah terdapat hubungan yang signifikan antara fisik dengan strategi koping pada pasien kanker yang menjalani kemoterapi di RSUD Prof. W Z Johannes Kupang. Koefisien korelasi menunjukkan adanya hubungan pada tingkat yang sangat lemah. Responden dengan kondisi fisik yang ringan yaitu responden dengan sedikit keluhan yang ditimbulkan oleh efek samping kemoterapi, dan responden dengan keluhan berat adalah responden yang mengalami efek samping dari kemoterapi seperti 
mual muntah, sulit buang air besar, diare, nyeri, sesak napas, infeksi, perdarahan, kesemutan, gangguan kulit, rambut rontok, gangguan pada mulut dan mata, penurunan nafsu makan, penurunan berat badan, fatigue, cemas, depresi, dan ganguan seksual..

Data distribusi menunjukkan bahwa mayoritas responden memiliki kondisi fisik yang sedang dengan strageti koping yang adaptif. Kondisi fisik yang baik dapat berhubungan dengan kondisi psikis dan strategi koping pada pasien yang sedang menjalani kemoterapi. Proses pemberian kemoterapi dapat berlangsung dalam waktu yang lama, sehingga diperlukan kondisi fisik yang kuat. Obat kemoterapi pada umumnya bersifat toksik dan mempunyai rentang aman yang sempit. Kemoterapi bekerja pada sel yang melakukan pembelahan secara cepat, sehingga selain sel kanker maka sel normal yang tumbuh dengan cepat pun akan dirusak oleh obat kemoterapi. Dosis kemoterapi ditentukan berdasarkan luas tubuh, berat badan, fungsi ginjal dan faal hati untuk mengurangi efek toksik dari obat kemoterapi, namun beberapa faktor seperti keadaan nutrisi pasien, keadaan umum, stadium kanker, serta penatalaksanaan sebelumnya juga mempengaruhi respon pasien terhadap pengobatan (20). Toksisitas kemoterapi dapat terjadi secara akut dalam hitungan jam ataupun setelah beberapa hari, minggu, bahkan beberapa bulan setelah pemberian obat (21).

Pasien dengan kondisi fisik yang berat atau lemah akibat efek samping dari kemoterapi dapat menyebabkan strategi koping pasien menjadi maladaptif. Hasil penelitian ini menunjukkan bahwa dengan kondisi fisik yang berat, stategi koping pasien adalah adaptif. Hal tersebut dapat disebabkan oleh lamanya responden dalam menjalani kemoterapi, serta besarnya keinginan pasien untuk sembuh, sehinggi pasien tetap melanjutkan kemoterapi demi kesembuhan. Dukungan keluarga juga mayoritas positif, sehingga strategi koping pasien bagus dan adaptif dalam menjalani kemoterapi.

Efek samping yang ditimbulkan oleh kemoterapi memberikan dampak terhadap penurunan status performa pasien kanker stadium lanjut. Pasien kanker stadium lanjut sering ditemui dalam kondisi kurang energi protein (KEP) atau yang dikenal dengan cachexia (22). Penelitian kualitatif terkait yang dilakukan oleh (23) didapatkan bahwa cachexia ditandai dengan penurunan nafsu makan dan berdampak terhadap penurunan ketahanan fisik pasien.

Efek samping kemoterapi berupa mual muntah juga akan mempengaruhi asupan makanan, apabila tidak ditangani secara cepat dan cermat lamakelamaan akan menyebabkan malnutrisi. Dampak dari keadaan ini adalah terjadinya penurunan kemampuan tubuh untuk toleransi terhadap pengobatan. Perubahan metabolisme yang berhubungan dengan kehilangan massa otot dan kekurangan tenaga juga mempengaruhi quality of life dan status fungsional. Pasien kanker sebanyak 75\% memiliki masalah kesehatan fisik dan psikologis yang berhubungan dengan terapi kankernya (24).
Masalah psikologis yang dialami pasien kanker stadium lanjut bersumber dari penurunanan kondisi fisik akibat penyakit dan efek samping terapi yang sedang dijalani. Tekanan psikologis pada pasien kanker yang menjalani pengobatan terutama kemoterapi perlu ditentukan dan dipahami. (25) mengatakan bahwa kejadian alopesia sebagai efek samping yang dialami penderita dapat mengganggu citra diri, kepercayaan diri, dan memberikan trauma tambahan yang akan berpengaruh terhadap kepatuhan pasien dalam menjalani kemoterapi. Koping dibutuhkan pasien sebagai upaya menghadapi ancaman fisik dan psikososial dalam menyikapi perubahan fisik dan psikologis yang diakibatkan efek kemoterapi, pasien memerlukan koping yang baik agar terapi menjadi efektif (26).

Peneliti berpendapat bahwa strategi koping yang adaptif juga dapat dipengaruhi oleh kondisi fisik yang baik dari respoden. Data juga menujukkan bahwa mayoritas kondisi fisik pasien adalah dalam kategori sedang. Hal ini juga dapat dipengaruhi oleh usia responden pada penelitian ini yang mayoritas adalah dewasa akhir dimana responden dapat lebih kuat dalam mengatasi efek samping yang ditimbulkan oleh kemoterapi. Peneliti juga berpendapat kalau kondisi fisik yang dipengaruhi efek samping kemoterapi juga dapat disebabkan oleh jenis dan stadium dari kanker itu sendiri.

Hasil dalam penelitian ini mayoritas responden dengan kanker stadium 2. Penatalaksanaan kemoterapi pasti juga berdasarkan dengan stadium dari kemoterapi. Sehingga efek samping yang ditimbulkan tidak terlalu berat. Selain itu juga dapat disebabkan dari sudah berapa kalinya responden melakukan kemoterapi. Responden yang sudah melakukan kemoterapi lebih dari 3 kali, biasanya tubuh sudah mulai mengalami penyesuaian dengan obat kemoterapi sehingga efek samping yang ditimbulkan tidak terlalu berat.

Peneliti menemukan bahwa efek samping yang ditimbulkan dari kemoterapi dapat berbeda - beda dari setiap orang. Tergantung dari kondisi fisik resonden itu sendiri. Ada dua responden yang samasama sedang melakukan kemoterapi untuk kedua kalinya, satu responden mengamali mual muntah hebat, tetapi responden satunya tidak mengalami mual. Sehingga efek samping kemoterapi juga tergantung dari kondisi fisik dan biologis dari masing-masing responden. Sehingga dapat dilakukan penelitian lebih lanjut, apa yang dapat membuat responden yang menjalani kemoterapi tidak mengalami efek samping dari kemoterapi yang begitu hebat.

\subsection{Faktor emosi}

Hasil analisis dengan uji statistik korelasi Spearman's $R^{\prime} h o$ adalah terdapat hubungan yang sangat signifikan antara suasana emosi dengan strategi koping pada pasien kanker yang menjalani kemoterapi di RSUD Prof. W Z Johannes Kupang. Koefisien korelasi menunjukkan adanya hubungan pada tingkat yang cukup. 
Data distribusi menunjukkan bahwa mayoritas suasana emosi responden dalam kategori kurang seperti responden yang tidak bisa mengontrol emosi sehingga mudah marah, pesimis, dan mudah putus asa diikuti dengan strategi koping yang adaptif yang meliputi tidak memiliki pikiran negatif, responden dapat menyesuaikan dengan kondisi saat ini, dapat menyadari adanya perubahan pada dirinya, serta dapat menerima kondisi penyakit saat ini. Hal tersebut dapat dapat disebabkan dari lama pasien yang sudah menjalani kemoterapi. Respon yang sedang menjalani kemoterapi akan mengalami ketidakstabilan emosi akibat efek samping dari obat kemoterapi. Namun koping responden tetap baik dikarenakan responden ingin sembuh dari penyakit kanker yang dideritanya. Data distribusi pada penelitian ini juga menunjukkan bahwa koping yang adaptif juga karenakan oleh susana emosi yang baik dari responden. Respon menjalani kemoterapi dengan baik, patuh dan iklas, sehingga emosi pasien dapat stabil.

Koping responden yang adaptif dan baik pada pasien kanker yang menjalankan kemoterapi tidak terlepas dari sumber koping yang merupakan keadaan yang dapat membantu seseorangdalam menentukan pilihan untuk mengatasi berbagai masalah dan stressor yang dihadapi. Beberapa sumber koping antara lain meliputi aset ekonomi, kemampuan dan ketrampilan personal yang dimiliki, keyakinan positif, dukungan sosial dan motivasi personal untuk menyelesaikan masalah (27).

Sumber koping terdiri atas dua faktor yaitu faktor internal dan eksternal (27). Faktor internal terdiri dari kesehatan dan energi, system kepercayaan seseorang termasuk kepercayaan eksistensial (iman, kepercayaan, agama). Responden dengan iman dan kepercayaan yang baik terhadap agama dan tuhannya akan memiliki koping yang adaptif saat tertimpa musibah atau cobaan. Komitmen atau tujuan hidup (Property motivasional). Responden kanker dengan kemoterapi membuhutuhkan dukungan yang positif dari keluarga dan lingkungan sekitar, sehingga responden dapat memiliki motivasi yang baik dan tujuan yang jelas serta dapat bertahan dari penyakit kanker. Perasaan seseorang seperti harga diri, kontrol dan kemahiran, ketrampilan sosial (kemampuan berkomunikasi dan berinteraksi dengan orang lain). Responden dengan kanker biasanya mengalami penurunan harga diri dan kepercayaan, sehingga responden kanker perlu membutuhkan sugesti dan cerita yang positif. Faktor eksternal terdiri atas dukungan sosial dan sumber material selama menjalani proses pengobatan.

Diagnosis kanker mempengaruhi penderitanya hampir pada seluruh setiap aspek kehidupan pasien diantaranya aspek fisik, psikologis, interpersonal, vokasional, dan spiritual. Individu yang didiagnosis kanker diusia yang lebih muda (sebelum 45) telah ditemukan berisiko tinggi untuk mengalami masalah psikologis, yang dapat bertahan dalam perkembangan kehidupannya (28). Menurut (15) salah satu cara yang mungkin bisa dilakukan bagi penderita kanker yang baru terdiagnosis dalam mengontrol tekanan emosional adalah dengan mekanisme koping yang baik.

Mekanisme koping yang baik dapat meningkatkan pikiran positif dari pasien. Pasien akan selalu berpikir positif dan optimis akan kesembuhan dari penyakit yang dideritanya. Pasien kanker dapat memiliki tekanan emosional yang tinggi seperti mudah stress, mudah tersinggung, dan mudah putus asa dalam menjalani kemoterapi, sehingga diperlukan koping yang adapatif. Faktor lain yang juga berhubungan dengan suasana emosi responden saat menjalani kemoterapi adalah pelayanan yang diberikan oleh perawat kepada responden. Penelitian yang dilakukan oleh (5) menunjukan bahwa pelayanan dan dukungan yang diberikan oleh perawat yang dikombinasikan dengan dengan perawatan yang kompeten dapat meningkatkan rasa percaya diri dan membuat mereka merasa (lebih baik) serta mampu menangani gejala mereka. Pentingnya pasien dianggap berasal dari intervensi bervariasi sesuai dengan pengalaman gejala individu dan mekanisme koping pasien, dan oleh pengalaman mereka dengan perawatan rutin.

Hasil penelitian menunjukkan bahwa kondisi atau suasana emosi responden adalah dalam kategori kurang. Hal yang dimaksud adalah gambaran atau ketidaknyamanan atau ketakutan, atau kekhawatiran dari responden akan tindakan setelah kemoterapi adalah rendah. Koping pasien dalam melakukan tindakan kemoterapi adalah adaptif. Hal ini dapat disebabkan karena motivasi dan keinginan dari responden yang kuat untuk sembuh, sehingga responden selalu berpikiran positif dan tidak terlalu memikirkan efek dari kemoterapi yang akan ditimbulkan. Tentu hal ini merupakan suatu hal yang positif dan baik bagi kesehatan dari responden.

\subsection{Konsep diri}

Hasil analisis dengan uji statistik korelasi Spearman's R'ho adalah terdapat hubungan yang sangat signifikan antara konsep diri dengan strategi koping pada pasien kanker yang menjalani kemoterapi di RSUD Prof. W Z Johannes Kupang. Koefisien korelasi menunjukkan adanya hubungan pada tingkat yang cukup.

Data distribusi pada penelitian ini menunjukkan bahwa mayoritas konsep diri responden adalah baik dan diikuti dengan strategi koping yang adaptif. Hal tersebut dikarenakan responden yang memiliki konsep diri yang baik dapat menjalani kemoterapi dengan baik serta koping yang adaptif. konsep diri dapat diperoleh melalui orang lain dan diri sendiri. Aspek utama konsep diri adalah dicintai, disayangi, dikasihi orang lain dan mendapat penghargaan dari orang lain. Apabila kehilangan kasih sayang atau cinta kasih dari orang lain, kehilangan penghargaan diri dari orang lain dan adanya hubungan interpersonal yang buruk akan berdampak munculnya konsep diri rendah. Sebaliknya, individu akan merasa berhasil atau hidupnya bermakna apabila diterima dan diakui orang lain atau merasa mampu menghadapi 
kehidupan dan mampu mengontrol dirinya. Individu yang sering berhasil dalam mencapai cita-citanya akan menumbuhkan perasaan konsep diri yang tinggi atau sebaliknya (29).

Data distribusi pada penelitian ini juga menunjukkan sebagaian besar responden dengan konsep diri yang kurang juga diikuti dengan strategi koping yang maladaptif. Hal tersebut dapat disebabkan karena pasien tidak percaya dengan keberhasilan dari proses pengobatan kemoterapi atau pasien merasa takut dengan efek kemoterapi yang ditimbulkan. Penelitian (30) tentang proses koping pada pasien kanker ditemukan tiga proses koping yang digunakan untuk mengatasi krisis akibat penyakit kanker, pengobatan dan perawatan yang dijalani. Pertama adalah pemikiran negatif (negative feelings) yang terdiri dari dua aspek yaitu distress mental dan kehilangan kontrol fisik. Distress mental berupa kekhawatiran dan ketakutan, antisipasi yang buruk, syok, putus asa, marahs, rasa tidak adil, dan penyangkalan sedangkan kehilangan kontrol fisik berupa ketidaknyamanan fisik yang dialami pasien kanker seperti gangguan tidur, keletihan dan kehilagan nafsu makan.

Mekanisme koping selanjutnya yaitu penyesuaian diri (self-adjustment) adalah penyesuaian diri pasien terhadap keyakinan pribadi dan gaya hidupnya untuk mengatasi stres akibat diagnosis kanker, perawatan dan pengobatan yang dijalani. Penyesuain diri terdiri dari dua aspek yaitu penyesuaian terhadap keyakinan pribadi dan penyesuaian terhadap gaya hidup. Penyesuaian terhadap keyakinan pribadi adalah penyesuaian yang dilakukan pasien kanker untuk mempersiapkan diri dalam menghadapi dampak penyakit kanker. Berbagai penyesuaian positif yang dilakukan untuk menerima diagnosis kanker adalah pikiran yang konstruktif, penerimaan terhadap fakta yang ada, meningkatkan motivasi, memperbaiki kenyamanan diri dan berdoa untuk ketenangan pikiran sedangkan sedangkan penyesuaian terhadap gaya hidup berupa penyesuaian terhadap perubahan diet, olahraga, jadwal kerja, dan penyesuaian beban kerja yang ada.

Mekanisme koping yang terakhir adalah reinterpretasi diri (self-reinterpretation) merupakan perubahan dalam sistem nilai dimana pasien kanker harus merubah keyakinan lama yang sudah ada pada diri mereka. Pentingnya melepaskan diri dari perasaaan negativ, menyadari akan pentingnya informasi dan harapan yang realistik akan penyakit yang membutuhkan penyesuaian diri, dan melakukan evalusi ulang terhadap kehidupan mereka. Konsep diri yang positif dari responden yang menjalani kemoterapi perlu dibangun sehingga dapat menimbulkan konsep koping yang adaptif. Saat responden memandang dirinya baik dari fisik, emosi, dan keberhasilan dari pengobatan yang dijalaninya, itu akan memberikan dampak positif sehingga responden akan melanjutkan pengobatan terus hingga selesai. Konsep diri yang positif dapat dibangun dari interaksi antara perawat dengan responden, atau sesama responden selama menjalani kemoterapi.

\subsection{Dukungan keluarga}

Hasil analisis dengan uji statistik korelasi Spearman's R'ho adalah terdapat hubungan yang sangat signifikan antara dukungan keluarga dengan strategi koping pada pasien kanker yang menjalani kemoterapi di RSUD Prof. W Z Johannes Kupang. Koefisien korelasi menunjukkan adanya hubungan pada tingkat yang cukup. Dukungan keluarga yang positif dapat dibelikan melalui memenuhi kebutuhan infomasi yang diperlukan oleh pasien, memberikan dukungan instrumen yang meliputi pemenuhan setiap kebutuhan dan peralatan yang diperlukan oleh pasien serta dukungan emosional an harga dari yang dapat diberikan dengan keluarga selalu ada untuk pasien dalam memberikan perawatan.

Hasil penelitian ini menunjukkan bahwa mayoritas responden mendapat dukungan keluarga yang baik dari orang tua ataupun keluarga dan kerabat dekat. Hal tersebut menyebabkan strategi koping pasien yang adaptif dalam menjalani kemoterapi. Salah satu faktor yang mempengaruhi strategi koping pada pasien yang menjalani kemoterapi menurut (13) adalah dukungan dukungan sosial yang meliputi dukungan pemenuhan kebutuhan informasi dan emosional pada diri individu yang diberikan oleh orang tua, anggota keluarga lain, saudara, teman, dan lingkungan masyarakat sekitarnya.

Dukungan sosial sebagai rasa memiliki informasi terhadap seseorang atau lebih dengan dua kategori dukungan harga diri berupa pengakuan dan dukungan harga diri. Pengakuan dari seseorang untuk merasa dicintai. Pasien kanker sering memiliki harga diri rendah terkait dengan jenis kanker yang diderita. Pasien dengan kanker sering merasa malu dan pesimis dengan progres penyembuhan dari penyakit yang didierita. Sehingga pasien kanker memelurkan keluarga yang dapat memberikan cinta dan kasih dengan tulus.

Dukungan harga diri yang berupa pengakuan di seseorang akan kemampuan yang dimiliki. Pasien dengan kanker sering dianggap sudah tidak dapat melakukan apapun, sehingga keluarga dan tetangga sekitar seperti tidak memberikan kesempatan bagi pasien tersebut untuk melakukan suatu kegiatan atau tindakan. Pasien dengan kanker dengan kondisi yang sehat dan bugar juga memiliki harapan untuk dapat diperlakukan layaknya orang sehat. Sehingga keluarga dapat mempertimbangkan kemampuan pasien sesuai dengan kemampuan yang dimiliki, sehingga pasien dengan kanker dapat manjalani hidup dengan produktif.

Keluarga merupakan aspek yang sangat penting dalam pengobatan kemoterapi yang sedang dijalani partisipan. Dukungan dari keluarga yang didapat partisipan ialah berupa motivasi, keberadaan dan perhatian. Seluruh partisipan mengaku dukungan yang didapat sangat membantu kondisi psikologis mereka untuk kuat dan tetap semangat dalam 
menjalani pengobatan kemoterapi. Sesuai dengan hasil penelitian yang dilakukan oleh (31) pada pasien kanker yang menjalani kemoterapi bahwa berdasarkan dukungan emosional keluarga dalam kategori baik yaitu 52\% pasien menerima dukungan emosional dari keluarga. Terdapatnya dukungan dari keluarga akan membuat pasien tidak merasa sendiri dan pasien merasa bebannya berkurang karena dapat mencurahkan segala yang dirasakannya kepada keluarga. Dukungan keberadaan yang diberikan keluarga dapat membantu partisipan terhadap penguasaan emosi yang dapat timbul saat menjalani pengobatan kemoterapi. Dukungan keluarga yang dapat diberikan oleh keluarga meliputi dukungan materil serta imateril seperti selalu menemani pasien setiap melakukan kemoterapi, memberi hiburan, serta dapat menjadi tempat bercerita.

Hasil penelitian ini sesuai dengan penelitian (32) menemukan bahwa harapan yang paling besar diinginkan pasien adalah dukungan dari kelompok dan pusat pelayanan kesehatan dan selalu berkeinginan diajak untuk berbicara dengan orang lain untuk mengatasi penyakit dan kerasnya efek kemoterapi. Komunikasi antara pasien, perawat dan keluarga pasien adalah hal yang diinginkan partisipan terhadap perawat. Partisipan mengakui komunikasi yang baik dari perawat membantu keadaan psikologis mereka. Sesuai dengan hasil penelitian yang dilakukan oleh (3) bahwa pasien berpendapat perawat yang bias memuaskan pasien adalah perawat yang bias mengerti kondisi pasien, sabar, lemah lembut, memberikan semangat, dan memperhatikan kondisi pasien secara keseluruhan. Semua hal yang diinginkan pasien berpusat pada komunikasi perawat.

Dukungan emosional yang diberikan oleh keluarga mampu memberikan rasa nyaman, merasa di perhatikan dan diicintai, memberikan bantuan dalam bentuk semangat, perhatian serta individu yang menerima dukungan tersebut merasa berharga. Dukungan instrumental, meliputi dukungan jasmaniah, dukungan materi, dalam bentuk nyata seperti keuangan yang intinya adalah suatu kondisi dimana benda atau jasa dapat membantu memecahkan masalah yang dihadapi. Dukungan ini ditunjukan dengan pendampingan keluarga kepada klien saat ke RS untuk memenuhi jadwal kemoterapi (33).

\section{KESIMPULAN}

Kondisi fisik baik yang diakibatkan oleh efek samping kemoterapi, suasana emosi dan konsep diri yang baik serta dukungan positif dari keluarga dapat membuat strategi koping pasien kanker yang menjalani kemoterapi di RSUD Prof. Dr. W.Z. Johanes Kupang dari maladaptif menjadi adaptif. Peneliti selanjutnya dapat mengembangkan intervensi keperawatan dengan pemberian konseling kepada pasien, sehingga dapat menceritakan keluhan dan perasaan yang dialami selama menderita kanker dan menjalani kemoterapi dan dapat meningkatkan koping pasien saat menjalani kemoterapi, serta dapat melakukan penelitian dengan menambahkan faktor self efficacy dan faktor budaya menggunakan pendekatan transcultural nursing theory.

\section{UCAPAN TERIMA KASIH}

Kami mengucapkan terima kasih kepada Direktur Rumah Sakit Prof. W Z Johannes Kupang untuk izin dan penerimaan kami untuk mengambil data sebagai bahan penelitian dan semua responden yang telah bersedia menjadi responden.

\section{DAFTAR PUSTAKA}

1. Institute NC. What is Cancer? National Cancer Institute. 2015.

2. You J, Wang C, Rodriguez L, Wang X, Lu Q. Personality, coping strategies and emotional adjustment among Chinese cancer patients of different ages. Eur J Cancer Care (Engl) [Internet]. 2018 Jan [cited 2018 May 14];27(1):e12781. Available from: http://doi.wiley.com/10.1111/ecc.12781

3. Chan H, Ismail S. Side Effects of Chemotherapy among Cancer Patients in a Malaysian General Hospital: Experiences, Perceptions and Informational Needs from Clinical Pharmacists. Asian Pacific J Cancer Prev. 2014;15(13):53059.

4. Lorusso D, Bria E, Costantini A, Massimo Di M, Rosti G, Mancuso A. Patients ' perception of chemotherapy side effects : Expectations , doctor - patient communication and impact on quality of life - An Italian survey. Eur J Cancer Care (Engl). 2016;(November):1-9.

5. Coolbrandt A, Milisen K, Wildiers H, Aertgeerts B, van Achterberg T, Van der Elst E, et al. A nursing intervention aimed at reducing symptom burden during chemotherapy (CHEMO-SUPPORT): A mixed-methods study of the patient experience. Eur J Oncol Nurs [Internet]. 2018 Jun 1 [cited 2018 May 14];34:35-41. Available from: http://linkinghub.elsevier.com/retrieve/pii/S1 462388918300395

6. Dhooria GS, Singh HP, Bhat D, Bains HS, Soni RK, Kumar M. Multidimensional impact on families of children with steroid-sensitive nephrotic syndrome. J Paediatr Child Health [Internet]. 2017 Apr 1 [cited 2018 Mar 7];53(4):354-7. Available from: http://doi.wiley.com/10.1111/jpc.13445

7. Rosenberg AR, S M, Bona K, H MP, Ketterl T, D M, et al. Intimacy, Substance Use, and Communication Needs During Cancer Therapy: A Report From the "Resilience in Adolescents and Young Adults "Study. J Adolesc Heal. 2017;60(1):93-9. 
8. Komiya T, Mackay CB, Chalise P. Who treats lung cancer? Results from a global. Respir Investig. 2017;55(5):308-13.

9. Riskesdas (Riset Kesehatan Dasar). Riset Kesehatan Dasar. Jakarta; 2013.

10. KEMENKES RI. Riset Keshatan Dasar (RISKESDAS 2013). Badan Penelitian dan Pengembangan Kesehatan Kementerian Kesehatan RI. JAKARTA: Badan LITBANG KEMENKES RI; 2013. 1-306 p.

11. Kemenkes (Menteri Kesehatan Republik Indonesia). Peraturan Menteri Kesehatan RI no 11 tahun 2017 tentang Keselamatan Pasien. Jakarta: Kementerian Kesehatan RI; 2017.

12. Pergament KI. The psycology of religion and coping: theory, research. New York: The Guilford Press; 1997.

13. Lazarus RS, Folkman.S. Stress, appraisal, and coping. . New York, USA: Springer Publishing Company; 1984.

14. Taylor SE, Stanton AL. Coping Resources, Coping Processes, and Mental Health. Annu Rev Clin Psychol [Internet]. 2007 Apr [cited 2018 May 14];3(1):377-401. Available from: http://www.annualreviews.org/doi/10.1146/a nnurev.clinpsy.3.022806.091520

15. Loprinzi CE, Prasad K, Schroeder DR, Sood A. Stress Management and Resilience Training ( SMART ) Program to Decrease Stress and Enhance Resilience Among Breast Cancer Survivors: A Pilot Randomized Clinical Trial. Clin Breast Cancer. 2011;11(6):364-8.

16. Ahadi H, Delavar A, Rostami AM. Comparing Coping Styles in Cancer Patients and Healthy Subjects. Procedia - Soc Behav Sci. 2014;116:3467-70.

17. Yunitasari E. Pengembangan Model Asuhan Keperawatan Koping dalam Upaya Meningkatkan Resiliensi Pasien Kanker Serviks Post Radikal Hysterectomy + BSO yang Mendapatkan Kemoterapi Berbasis Adaptasi Roy. Universitas Airlangga; 2016.

18. Krohne HW. Stress and Coping Theories. Germany; 2002.

19. Lord JH, Rumburg TM, Jaser SS. Staying positive: Positive affect as a predictor of resilience in adolescents with type 1 diabetes. J Pediatr
Psychol. 2014;40(9):968-77.

20. Chu E, Devita VT. Physicians' Cancer Chemotherapy Drug Manual. Sudbury: Massachuset Jones and Bartlett; 2008.

21. Airley R. Cancer Chemotherapy. Oxford: John Wiley \& Sons Ltd.; 2009.

22. Jatoi. Anorexia and cachexia. Cancer Immunol Immunother. 2014;12(2):112-6.

23. Huda N. Studi fenomenologi: Pengalaman cachexia pasien kanker stadium lanjut dan keluarga yang merawat di RS Kanker Dharmais Jakarta. Keperawatan Indones. 2014;3(2):11-6.

24. Potter PA, Perry AG. Fundamentals of Nursing Fundamental Keperawatan. 7th ed. Nggie dr AF, editor. Jakarta: Salemba Medika; 2009.

25. Grubaugh ML, Flynn L. Relationships among Nurse Manager Leadership Skills, Conflict Management, and Unit Teamwork. J Nurs Adm. 2018;48(7-8):383-8.

26. Aufa R. Hubungan mekanisme koping dengan stress pada pasien kanker dalam mengatasi efek samping kemoterapi di ruangan kemoterapi bedah wanita RS. DR. M. Djamil. Keperawatan Indones. 2010;3(1):12-7.

27. Stuart GW. Principles an Practice of Psichiatric Nursing. 10th ed. St Louis, Missouri 63043: Mosby, an imprint of Elsevier Inc; 2013.

28. Hoffman MA, Lent RW, Raque-Bogdan TL. A Social Cognitive Perspective on Coping With Cancer. Couns Psychol. 2013;41(2):240-67.

29. Sunaryo. Psikologi untuk Keperawatan. Jakarta: EGC; 2004.

30. Chen PY, Chang HC. The coping process of patients with cancer. Eur J Oncol Nurs. 2012;16(1):10-6.

31. Hanahan D, Weinberg RA. Hallmarks of cancer: the next generation. Cell. 2011;144(5):646-74.

32. Ohayon IH, Braun M. Being A Parent and Coping with Cancer: Intervention Development. J Palliat Support Care. 2010;9:149-52.

33. Gao L, Sun K, Chan SW. Social support and parenting self-ef fi cacy among Chinese women in the perinatal period. Midwifery. 2014;30(5):532-8. 